\title{
Electrical impedance spectroscopy and colposcopy for cervical intraepithelial lesions and cervical cancer detection
}

\begin{abstract}
The early detection of cervical intraepithelial lesions represents an important tool to fight against cervical cancer, which leads to decreasing the high rates of incidence and mortality that this pathology presents in developing countries. The use of new diagnostic techniques helps in achieving this objective. The purpose of this paper is to show that the Electrical Impedance Spectroscopy (EIS) is a technique that complements colposcopy to improve the sensitivity and specificity in the diagnosis and management of this pathology.
\end{abstract}

Keywords: colposcopy, electrical impedance spectroscopy, cervical squamous tissues, cervical intraepithelial lesions, cervical cancer detection
Volume 7 Issue 3 - 2018

\author{
Gallego-Sánchez PA,' Olarte-Echeverri G, \\ Rojas-Díaz J, ${ }^{3}$ Aristizábal-Botero W ${ }^{4}$ \\ 'Médico y Cirujano, Ginecólogo-Obstetra, Ginecólogo- \\ Oncólogo. Investigador Universidad de Caldas, Colombia \\ 2Médico y Cirujano, Ginecólogo-Oncólogo, Investigador \\ Universidad de Caldas, Colombia \\ ${ }^{3}$ Departamento de Física, Universidad de Caldas, Colombia \\ ${ }^{4}$ Especialista en Bioingeniería y Bioelectrónica, Investigador \\ Universidad de Caldas, Colombia
}

Correspondence: William Aristizábal-Botero, Scientific Researcher, Caldas University Manizales, Headquarters Calle 65 $N^{\circ}$ 26- I0-Manizales, (Caldas), Colombia, Tel (57) (6) 878I500, Ext II677,Email william.aristizabal@ucaldas.edu.co

Received: April 16, 2018 | Published: June 07, 2018

\section{Introduction}

Cervical cancer is the fourth most common cancer for women in the world, and the seventh overall, with an estimated 528,000 cases in 2012. Its geographic distribution is irregular and it is more likely to occur in developing countries. The $87 \%$ cervical cancer deaths occur in less developed regions. ${ }^{1}$ The incidence and mortality age-adjusted rates were respectively 19,3 and 8,2 per 100000 women for Colombia between $2007-2011 .^{2}$ To improve the sensitivity in intraepithelial lesions and invasive cancer detection, new technologies such as liquidbased cytology ${ }^{3}$ visual inspection methods with acetic acid and lugol's iodine (VIA, VILI), ${ }^{4-6}$ EIS $^{7-14}$ and optical fluorescence spectroscopy ${ }^{15}$ have permitted the achievement of diagnostic sensitivity greater than $70 \%$.

\section{Electrical impedance spectroscopy}

EIS is a technique used in the characterization of different materials and especially in biological tissues. ${ }^{16}$ EIS is a useful technique for the detection and characterization of cervical intraepithelial lesions, with diagnostic precision greater than $75 \%$, with sensitivity and specificity over $69 \%$, similar to other detection methods of cervical intraepithelial lesions. ${ }^{12,13}$ EIS has an acceptable positive predictive value and a negative predictive value close to $90 \%{ }^{14}$ while the sensitivity of conventional Pap smear in detecting cervical lesions before cervical cancer is $51 \%$, which means the false negative value is $49 \% .{ }^{17}$

The EIS is a technique that has been developed in the Medical Physics Department at Sheffield University (England) by Brown and colleagues, with application in pre-invasive cervical lesions..$^{7-11}$ In Australia, Coppleson and colleagues have performed works using a combination of electrical impedance spectroscopy and optical fluorescence. ${ }^{15}$ In Colombia, the Cervical Cancer and Breast Cancer Research Group at Caldas University have reported results found in its population for intraepithelial lesions and invasive cervical cancer. ${ }^{12-14}$

The EIS technique is based on the application of a small alternating current on the tissue around 20 microamps, using a tetrapolar probe constructed with four gold electrodes: two current electrodes and two voltage electrodes. The probe is calibrated using a saline solution with known conductivity. The current is supplied by a controlled source through two electrodes called current electrodes. The potential difference between points of the tissue affected by the electrical field is measured by the other pair of electrodes, called voltage electrodes (Figure 1).

The tissue transfer impedance to each of the frequencies is obtained from the relationship between the measured voltage and the applied current. With the impedance values calculated and the different frequencies, curves or spectra can be constructed and allow the association of each curve with the different tissue types and their pathological states (Figure 2).

With the curves obtained, it is possible to calculate some parameters that can be associated with the different types of tissues and which are in correspondence with a representation of the tissues through electrical circuits and mathematical models. ${ }^{18}$ In this modeling it is common to associate intracellular and extracellular spaces with resistors and the cell membrane with capacitors, that is, the associated circuit is made up of two branches: The first, a resistor that represents the resistivity of the extracellular space and the second, in parallel with the first, the series of another resistor that models the resistivity of the cytoplasm and the capacitor that models the cell membrane., ${ }^{7,12}$

It has been found in some investigations that the magnitude of tissue impedance decreases with the increase in the degree of the lesions. The impedance at low frequencies is high in normal squamous tissues, in order of 20 ohms-meter, tissues that have low-grade lesions (HPV, 
CIN 1) present values between 8 and 10 ohms-meter and tissues with high-grade lesions (CIN 2/3 and cancer in situ) can fall to 3 or 4 ohmmeter. ${ }^{11-13}$ From the histological point of view, the changes in tissue impedance can be explained through the structural changes that occur in them when dysplastic lesions are present. These changes are mainly the increase of the extracellular space, the breaking of the intercellular bridges and the increase of the nucleus-cytoplasm ratio. ${ }^{19}$ All these changes cause the resistivity of the tissue to decrease.

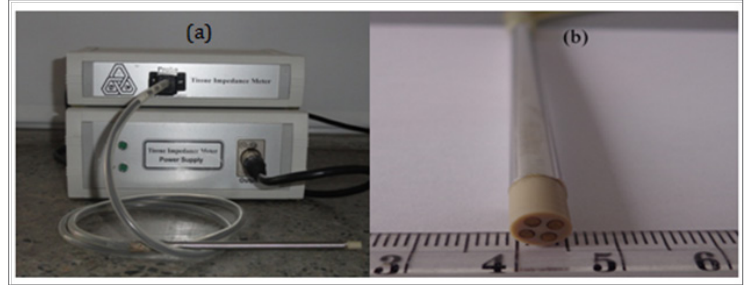

Figure I(a) Tissue impedance meter MK 3.5 (b) Tetrapolar probe.

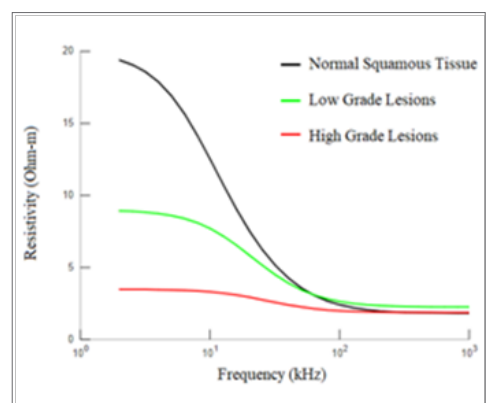

Figure 2 Tissue resistivity curves for cervical squamous tissue.

\section{Discussion}

EIS can evaluate the shape, internal organization and structure of the cellular tissues, noninvasively. The advantages offered by the EIS are its low cost, its low invasiveness and easiness of application and interpretation; ${ }^{12}$ this means that this diagnostic technique can offer an alternative that helps the physician that performs colposcopies in "seeing and treating strategies" in a single visit to patients who consult for pathologies of intraepithelial lesions in the cervix. It is important to highlight that colposcopy is the key element for a good use of the EIS. The physician determines the points of the cervix where the measurement probe must be placed. He also determines whether these measures are being performed on squamous or columnar epithelium, as well as if there is a suspicion of pre-invasive lesions or invasive cancer.

\section{Conclusion}

The colposcopic examination with EIS is a procedure performed in real time, achieving an immediate diagnosis and permitting the implementation of seeing and treating patients in a single visit and which can be proposed as a useful tool to improve the diagnostic precision of cervical squamous lesions for large populations in developing countries.

\section{Acknowledgements}

Innovation and Technological Development Center Ci2Dt2. Caldas University Sciences Health Faculty. Caldas University
Biophysical Instrumentation Laboratory. Funded with resources of Technology and Innovation Science Fund. Royalties General System (RGS-Colombia).

\section{Conflict of interest}

We declare that we have not conflict of interest.

\section{References}

1. Ferlay J, I Soerjomataram, R Dikshit, et al. Cancer Incidence and Mortality Worldwide: Sources, Methods and Major Patterns in GLOBOCAN 2012. Int J Cancer. 2015;136(5):E359-E386.

2. Pardo C, Cendales R. Incidencia, mortalidad y prevalencia de cáncer en Colombia, 2007-2011. In: Bogotá DC, editor. Instituto Nacional de Cancerología. Colombia: 2015;1:148.

3. Zhu J, Norman I, Elfgren K, et al. A comparison of liquid-based cytology and Pap smear as a screening method for cervical cancer. Oncol Rep. 2007;18(1):157-160.

4. Sankaranarayanan R, Nene BM, Dinshaw K, et al. Early detection of cervical cancer with visual inspection methods: a summary of completed and ongoing studies in India. Salud Pública Mex. 2003;45(Suppl 3):S399S407.

5. Sankaranarayanan R, Wesley R, Thara $\mathrm{S}$, et al. Test characteristics of visual inspection with $4 \%$ acetic acid (VIA) and Lugol's iodine (VILI) in cervical cancer screening in Kerala, India. Int J Cancer. 2003;106(3):404-408.

6. Basu PS, Sankaranarayanan R, Mandal R, et al. Visual inspection with acetic acid and cytology in the early detection of cervical neoplasia in Kolkata, India. Int J Gynecol Cancer. 2003;13(5):626-632.

7. Brown BH, Tidy JA, Boston K, et al. Relation between tissue structure and imposed electrical current flow in cervical neoplasia. Lancet. 2000;355:892-895.

8. Abdul S, Brown BH, Milnes P, et al. A clinical study of the use of impedance spectroscopy in the detection of cervical intraepithelial neoplasia (CIN). Gynecol Oncol. 2005;99(3 Suppl 1):S64-S66.

9. Abdul S, Brown BH, Milnes P, et al. The use of electrical impedance spectroscopy in the detection of cervical intraepithelial neoplasia . Int $J$ Gynecol Cancer. 2006;16:1823-1832.

10. Balasubramani L, Brown BH, Healy J, et al. The detection of cervical intraepithelial neoplasia by electrical impedance spectroscopy: The effects of acetic acid and tissue homogeneity. Gynecol Oncol. 2009;115(2):267271.

11. Brown BH, Milnes P, Abdul S, et al. Detection of cervical intraepithelial neoplasia using impedance spectroscopy: a propective study. BJOG: an International Journal of Obstetrics and Gynaecology. 2005,112:802-806.

12. Olarte G, Aristizabal W, Gallego PA, et al. Detección precoz de lesiones intraepiteliales del cuello uterino en mujeres de Caldas- Colombia mediante la técnica de espectroscopia de impedancia eléctrica. Rev Colomb Obstet Ginecol. 2007;58(1):13-20.

13. Olarte G, Aristizabal W, Osorio GF, et al. Espectroscopia de impedancia eléctrica en cáncer invasivo del cuello uterino en mujeres de Caldas (Colombia), 2008-2009. Rev Colomb Obstet Ginecol. 2010;61(1):28-33.

14. Olarte G, Aristizabal W, Gallego PA. Evaluation of electrical impedance spectroscopy for cervical intraepithelial lesions detection. Revista Biosalud. 2015;14(1):26-35.

15. Coppleson M, Reid Bl, Skladnev VN, et al. An electronic approach to the detection of precancer and cancer of the uterine cervix: a preliminary evaluation of Polarprobe. Int J Gynaecol Cancer. 1994;4(2):79-83. 
16. Dean DA, Ramanathan T, Machado D, et al. Electrical Impedance Spectroscopy Study of Biological Tissues. J Electrostat. 2008; 66(34):165-177.

17. Mojgan Karimi-zarchi, Leila Zanbagh, Alireza Shafii, et al. Comparison of Pap Smear and Colposcopy in Screening for Cervical Cancer in Patients with Secondary Immunodeficiency. Electron Physician. 2015;7(7):15421548 .
18. Cole KS, Cole RH. Dispersion and absorption in dielectrics. I. Alternating current characteristics. J ChemPhys. 1941;9:341-351.

19. Walker DC, Brown BH, Blackett AD, et al. A study of the morphological parameters of cervical squamous epithelium. Physio Meas. 2003;24(1):121-135. 